\title{
The Impact of Distribution Management On Guinness PLC Product Availability in Calabar
}

\author{
Ndem Samuel Etim \\ Department of marketing University of Calabar, Calabar \\ Ezekiel Maurice Sunday \\ Department of marketing University of Calabar, Calabar \\ Martin George Eni \\ Department of marketing University of Calabar, Calabar
}

\begin{abstract}
This study on the impact of distribution management on the product availability of Guinness Nigeria Plc in Calabar, focuses on how operational distribution management components such as channel conflict resolution, channel motivation and order processing can be used in ensuring the availability of Guinness products among channel intermediaries in Calabar, The study adopted the descriptive and survey research design, of which data was collected from a sample size of 34 channel intermediaries which covered major distributors, wholesalers and retailers of Guinness brands in Calabar who were selected based on the simple random sampling technique of which their responses were electronically analyzed using multiple regression as a statistical tool in SPSS version 20,the overall result of the $r$ - square of the regression model showed a significant predictability of channel conflict resolution, channel motivation, and order processing on product availability. However, order processing as an operational distribution management component had the most significant impact on the product availability of Guinness Nigeria Plc in Calabar. Thus, it was recommended that Guinness Nigeria Plc should focus more on expediting her order processing methods because it most significantly ensures the availability of a firm's product more than conflict resolution and channel motivation variables
\end{abstract}

Keywords: channel conflict resolution, channel motivation, order processing and product availability.

\section{INTRODUCTION}

Every productive firm is charged with the sole managerial responsibility of ensuring that her produced goods and services are readily made available to her consumers at the right time and in the right place and form. Based on this important managerial responsibility, production firms (Guinness Nigeria Plc) must ensure that distribution management is conducted in a way that suits the channel intermediaries because they are solely responsible for the transfer of the ownership in goods and the movement of those goods from the point of production to the point of consumption thereby ensuring product availability.Moreso, for a productive firm such as Guinness Nigeria, Plc to succeed in accomplishing the overall distribution management objective which is to ensure product availability distribution activities and institutions must carefully be planned, organized, directed, controlled and coordinated.

Thus, it is pertinent for firms to note that every of it productive effort ranging from man, machine, material, methods and money would amount to a wasted effort if the products of such an effort fails to be readily made available to its final consumers as at when and where they are needed, and as such, any product that has been produced, priced and promoted would be of no economic importance if such a product fails to be adequately placed in locations where it can 
easily be accessed and obtained by those in need of such a product in order to maximally satisfy their numerous consumer wants.

Based on the above premise, it can vividly be opined that the place (distribution) element among all the other marketing mix element (product, price and promotion) piggybacks all the marketing mix element by bridging the exchange gap existing between the producer and the consumer through the use of channel intermediaries like the wholesalers, retailers etc. as in the case of Guinness Nigeria Plc, to delivering both the product and its value to the various consumers of the firm.

Distribution as defined by Agbonifoh et al (1998) is simply the flow of title to goods and the movement of those goods from the point of production towards the point of consumption, further supporting the above view point, Ebitu (2003) sees distribution as comprising all those activities involved in moving goods and services and also delivering transferred titles in goods from the producer or seller to the buyer or final consumer.

Furthermore, product availability which is the major objective of distribution management is becoming a more important issue for consumers seeking convenient goods and as such, product availability as defined by the Guanzi Institute is simply how much of a product is available for purchase at any given time.

Conclusively, in a bid to accomplish the overall distribution objective which is to ensure product availability to consumers, the management of productive firms must accord to distribution management the priority it deserves by carefully coordinating the distribution management components such as channel conflict resolution, channel motivation and the physical distribution management activity which is order processing etc, in order to enable them effectively bridge the exchange gap existing between the producer and the consumer and also complete the scholarly circle of production by delivering the right product(s) to the right person(s) at the right time and in the right place.

\section{Statement of the problem}

Through critical examination it has been observed that distribution management is not accorded the most needed priority it deserves and this leaves Ducker (1973) with the opinion that distribution remains the economy's Dark Continent. Furthermore, most productive firms tend not to accord to distribution management the much needed priority it deserves by failing to carefully coordinate distribution activities like order processing, warehousing, transportation etc and the institutions like the distributors, wholesalers and retailers who are involved in transferring title in goods and the movement of goods from the point of production to the point of consumption.

The emphasis on distributional research has been on sale promotion with less impact on distribution management with emphasis on dealership channel management on soft and alcoholic drink business. The work is centered on the impact of channel conflict resolution, channel motivation and orders processing as there affect the availability of Guinness products.

\section{Objective of the study}

1. To examine the impact of channel conflict resolution on the availability Guinness product in Calabar

2. To ascertain the impact of channel motivation on the availability Guinness product in Calabar 
3. To evaluate the impact of order processing on the availability Guinness product in Calabar

\section{THEORETICAL FRAMEWORK}

The Goal setting theory of motivation remains the auspicious upon which this study on the impact of distribution management on the product availability of Guinness Nigeria Plc is anchored upon and as such, the goal setting theory simply has to do with the development of an action plan designed to guide and motivate a person or a group towards a goal. A goal is the aim of an action or task that a person consciously desire to achieve or obtain (Locke and Latham 2002). The goal setting theory as popularized by Edwin A. Locke in the mid-1960s involves the conscious process of establishing levels of performance in order to obtain a desired outcome and as such this theory remains essentially linked to task performance which is used to guide and motivate employees to effectively boost their performance. The goal setting theory encourages participants to put in substantial effort because every member in an organization has defined expectations from their roles hereby avoiding little rooms for inadequacies.

Thus, according to Pennsylvania State University (PSU, 2012) goals energizes people to extend more effort based on the effort required to reach a goal and the more difficult a goal is to be achieved the more effort is channeled towards the actualization of such a goal because the goal setting theory according to (PSU, 2014) states that the source of motivation is the desire and intention to reach a goal.Conclusively, in business, the goal setting theory explains the goals set by various manufacturers for their middlemen and a reinforcement of their behaviour with motivational incentives in order to actualize the set goals (Kim,1984).

\section{AN OVERVIEW ON DISTRIBUTION MANAGEMENT CONCEPT}

Distribution management simply deals with the coordination of all the activities and institutions involved in the transfer of ownership and the movement of goods from the point of production to the point of consumption (Ebitu, 2003).Based on the above definition, the management of distribution activities and institutions remains of vital concern to productive firms in the sense that every of the productive effort of the firm which ranges from men, machine, methods, materials and money would amount to a wasted effort if the products of such an effort fails to be readily made available to its final consumers where and when they are needed. Further, emphasizing on the importance of distribution management Ehikwe and Egboro (2014) opined that producing products that consumers' wants, pricing them correctly and developing a well-designed promotional plan is necessary but not sufficient in ensuring customer satisfaction rather the final part of the Jigsaw is distribution which ensures the availability of product.

Thus, for any organization or productive firm to be effective there must be an effective distribution management process which would convey finished products from the manufacturers down to the final consumers hereby actualizing the overall distribution management objective which according to Ebitu (2003) is providing ready availability to consumers. Hence, in a bid to actualize the above distribution objective, the distribution activities of channel intermediaries such as the wholesaler, retailer etc. needs to be carefully coordinated because a well-chosen channel constitutes a significant competitive advantage while a poorly conceived or chosen channel could ridicule the entire distribution system (Weise and Gershon, 2002), and as such, William et al. (1994) suggest 5 basic decision areas or steps needed to be taken in order to build or design an effective distribution channel of which would be considered in details as this study progresses. 
Therefore, the importance of distribution management cannot be undermined because irrespective of the fact that distribution still remains as the Economy's Dark Continent according to the management guru Peter Ducker. It still remains of great essence to productive firms because just as marketing piggybacks a business and its offering into the market place in Esu (2003) so also do an effective management of distribution activities and institutions deliver both the product and its value to the various customers of the firm. Hereby not just ensuring the availability of such a product but also increasing the value of the product through the creation of both Time and Place utility which is an important role of distribution in the marketing process (Onah and Thomas 2004).

Summarily, in order for productive firms to successfully manage its distribution channel and activities, such a firm must analyze end consumers, establish channel objectives, specify channel tasks, select an appropriate channel and evaluate the result of the entire process in order to determine if the above set activities are channeled towards the accomplishment of the overall distribution objective of such a firm (Hesket, 2003).

\section{Distribution channel}

The term distribution channel often times referred to as the marketing channel was first used according to Peltonet al (1997:7) by early writers to describe the existence of a trade channel that bridges both the producer and the consumer together. According to Bucklin (1966) in Ebitu (2003) a marketing channel comprises of a set of institutions which performs all of the activities utilized to move a product and its title from the point of production to the point of consumption.

\section{How to design a distribution channel}

Every firm engaged in the production of goods and services wants to design and adopt a distribution channel that will not only deliver the physical product to its various customers but also ensure that the right product(s) are delivered to the right person(s) at the right time and in the right place in order to ensure product availability and also maximally satisfy the various consumer needs and wants.Thus, in order for a firm to design a channel that is capable of satisfying consumer's needs and wants and also out do competition, an organized approach or steps are required (William et al, 1994), and this approaches includes:

a. Specifying the roles of distribution: This is the first step to be taken by productive firms in the course of designing a distribution channel that is capable of satisfying consumer needs and wants and also outdoing competition. This step requires the firm to first review its various marketing objectives in order to clearly specify the role of distribution. Here, the firm must decide whether distribution will be used either offensively or defensively. Using distribution offensively simply means that the firm intends using distribution to gain an added advantage over competitors while using distribution defensively means that the firm would strive to achieve a distribution channel that is as good as, but not necessary better than other firms distribution channels.

b. Selecting the type of channel: Once the distribution role in the overall marketing program has been agreed on in the first step, the most suitable type of channel for the firms product needs to be determined, and as a such, the firm under this step needs to decide the type of distribution channel to be selected in order to maximally satisfy consumer needs and wants and also ensure that the right product are delivered to the right people at the right time and place. More so, in this step the firm adopts or select any type of distribution channel be it direct or indirect channel as long as such a channel is capable of achieving the specified distribution or marketing objectives. 
c. Determining the intensity of distribution: This is the third step or approach in designing a distribution channel and in this step the firm has to determine the intensity of distribution activities needed in order to accomplish the overall distribution objectives of the firms. Thus, the firm having selected the type of distribution channel in the previous step has to now determine the kind of distribution strategy that would be adopted in order to give its product the necessary exposure it deserves within a particular geographical market.

d. Choosing specific channel members: This is the last step in designing a distribution channel and it requires the firm setting out criteria that would enable her in the selection of the various channel members who will handle and distribute the product of the firm in its various geographical markets.

In choosing specific channel members the firm always considers certain factors which ranges from those factors related to the market, the product and even the company itself. In order to ascertain if all those factors been considered are compatible with its distribution objectives.

Summarily, below is a diagrammatic representation showing the various steps or approaches to be followed when designing a distribution channel.

Fig. 1: Showing the steps or approaches on how to design a distribution channel.

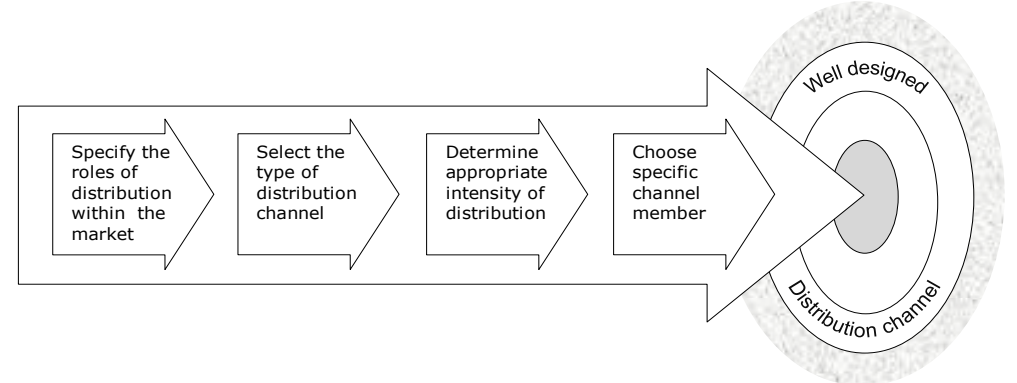

Source: Adapted from William et al (1994), fundamentals of marketing, Singapore: McGraw Hill Inc. pg. 366.

\section{Contextual review on the objectives of this study}

This contextual review is aimed at reviewing the relationship existing between the operational distribution management components such as channel conflict resolution, channel motivation as well as order processing and product availability.

\section{Channel conflict resolution and product availability}

Conflict simply means tension resulting from the incompatibility of the desired responses. According to Bowersox and Cooper (1992) conflict in the distribution channel occurs whenever channel members have distinctly different opinions or perceptions about distribution channel affairs.

Channel conflict often times steams from a situation in which one channel member perceivers another channel member to be engaged in behaviours that are inimical to the achievement of the set channel goals (Stern, Ansary and Coughan,1996).Conflict is common throughout the distribution channel in marketing and it can exist in any form among manufacturers, distributions or even retailers, and as such, according to Palamountain (1955) and supported by Cespedes and Cole (1990) three (3) major types of conflict exist among the channel of distribution members and they are the vertical, horizontal and the intertype conflict in which 
the vertical conflict is a type of conflict which usually occurs between intermediaries who are in the same level of distribution and different channels respectively.

More so, the conflict existing between the institutions in the channel of distribution passes through (2) two stages which are the perceptive stage in which a channel member perceives that conflict exist and the manifest stage in which the perceived conflict manifest showing the behaviours that occurs when one channel member is seen as frustrating another channel members effort in achieving his goal ( Pelton et al 1997).Therefore, due to the worrisome nature of conflict among the distribution channel members such as wholesalers, distributors and retailers, social scientists have carefully studied the basic causes of conflict in relation to distribution channel and their findings reveals that goal incompatibility, breakdown in communication, role incongruity, ideological and cultural differences, differences in role perception etc are the causes of channel conflict.

However, the above causes of conflict among channel members often leads to tension, hostility and inefficiency within the channel system which in a way can be commercially damaging for all parties involved and not just the manufacturer alone (Geoff and Reynolds 1998).Hence,when conflict arises among channel members some mechanisms or strategies are often required for the resolution of such conflict and according to Jain (1991), Bowesox and Copper (1992), Pelton et al (1997), Kotler and Keller (2007), such mechanisms includes the adoption of super ordinate goals, joint membership in trade association, cooperation, diplomacy, mediation or arbitration and legal resources.

Conclusively, the impact of channel conflict resolution on product availability can be seen from the words of Wikinson (1973) and Yagana (2004), who opined that the basic solution for channel conflict is effective cooperation among channel members and it is obtained when all channel members see themselves as a cooperate system, working together to achieve the whole objective.

\section{Channel motivation and product availability}

Motivation is simply defined as forces acting either on or with a person to initiate a behavior (encyclopedia Britannica,2013). The word motivation is derived from the Latin word "Motivus" which means a "moving cause". Thus, motivation is that which causes, energizes, directs and channels human behaviour in a working environment (Inyang, 2002).Hence, channel motivation simply means taking actions that fosters channel members cooperation in implementing the manufacturers distribution objective beyond compliance and active representation of product ( Gupta, 2013).

In today's competitive business environment which is characterized by the survival of the fittest syndrome, most productive firms tend to distribute its product through the use of channel intermediaries such as major distributors wholesalers, retailers etc. in order to ensure that their products gets to a large number of geographically scattered consumers which ordinarily their sales force cannot reach inorder to increase market share, cut cost, most competitive challenges and the difference in consumer behaviour (Savinhas and Anderson, 2005).

Thus, in a bid to achieve the above, it becomes a matter of necessity for productive firms to understand the needs and wants of its intermediary's in order to stimulate and encourage them to stock and market their product hereby ensuring the availability of such product within their respective geographical locals. More so, motivating channel intermediaries such as distributors wholesalers, retailers etc should be considered necessary by productive firms if 
their goods are to flow smoothly through the distribution channel, because motivation of channel intermediaries helps to build brand preference for the manufacturers product which in turn increases sales, influences channel member behaviours and above all ensures that the right products are at the right place and at the right time (Linton, 2014).

Furthermore, in motivating intermediaries productive firms can adopt inceptive marketing techniques which according to Buyline report (2008) includes trade contest, trade allowance, trade fairs etc. which when properly conducted can enhance the marketing performance and also facilitate the accomplishment of the firms distribution objectives. Supporting the above viewpoint, Kotleret al (2009) opined that to motivate intermediaries productive firms can use positive actions such as offering higher margins for advertising or display, and also negative actions such as threatening to cut back on margin or hold back delivery of product may also be necessary but however, most scholars opines that positive stimulators are more preferred to the negative one's in order to keep the intermediaries stimulated.

Conclusively, in order to ascertain the impact of channel motivation on the product availability of a firm Maritz motivation solutions conducted an in depth channel market study in 2013 to discover how effective channel representative incentives programs are, which factors best motivates channel reps to participate in an incentive programme and what communication methods and incentives are most effective $77 \%$ of managers, owners and sales representatives report that manufacturers sponsored reward and incentives programs have high influence on the willingness, interest and energy of intermediaries to sell and make available the manufacturers product and services.

\section{Order processing and product availability}

Order processing is a subsystem of physical distribution management that consist of a set of procedures for receiving, handling and filling orders (William etal ,1994). It has also been defined as a term used to identify the collective tasks associated with fulfilling an order for goods or services placed by a customer. The procedures or tasks involved in order processing when a physical product is ordered by a customer begins with the customer placing an order by submitting a written or an oral request through either a phone call, an online order form that is routed directly to the seller after which the seller receives the order and sends it to the distribution Centre which could be a structure or group of units used to store goods and merchandize that are to be delivered to various places as at when needed.

At the distribution centre the type and quantity of goods requested by the customer are collected and prepared for shipping, and once the order is received by the customer the customer inspects the goods to check for conformity with order and once it is confirmed to be in line with specification the order processing process can be termed to be complete. Thus, an efficient and accurate order processing is essential to the success of any business in the sense that it forms the basis for the information flow in a distribution or logistic system which in a way helps to plan, monitor and manage the flow of goods in order to ensure that the right product(s) are delivered to the right person(s) in the right place and at the right time. The order processing time which has to do with the expected period of time between the date an order is placed and when it is delivered is of serious concern to not just the manufacturers alone but to the consumers as well in the sense that a delay in the lead time in an order processing process can hamper the smooth flow of goods within the distribution channel hereby facilitating channel conflict which can be destructive and dysfunctional to the accomplishment of the overall distribution management objective which is to ensure product availability to consumers. 


\section{A Conceptual Framework and Model Showing the Impact of Distribution Management on the Product Availability of a Firm}

In today competitive business environment, producing products that consumers wants, pricing them correctly and developing a well-designed promotional plan is necessary but not sufficient in ensuring customer satisfaction, and as such, the Jigsaw is distribution which is the place element of the marketing mix (Ehikwe and Egboro, 2014).

Thus, the basis upon which this study is conducted is to determine the impact of distribution management on the product availability of Guinness Nigeria Plc of which the operational distribution management components such as channel conflict resolution, channel motivation and order processing remains x-rayed in order to determine if the coordination of such distribution management components could ensure product availability.Since, the distribution channels are not just economic entities but social systems characterized by both conflict and cooperation, William et al (1994) opines that in order to effectively manage distribution channels productive firm must have an understanding of both conflict and control including techniques to decrease the effect of conflict in distribution channel. Channel motivation on the other hand requires the use of incentive marketing techniques which includes trade contest, trade allowance, trade fairs etc, in order to motivate channel intermediaries to stock and carry the product of the manufacturer ( Buy line report 2008), while order processing as a term is used to identify the collective tasks associated with fulfilling an order for goods or services placed by a customer.

Fig 2: showing the impact of channel conflict resolution, channel motivation and order processing on the product availability of a firm.

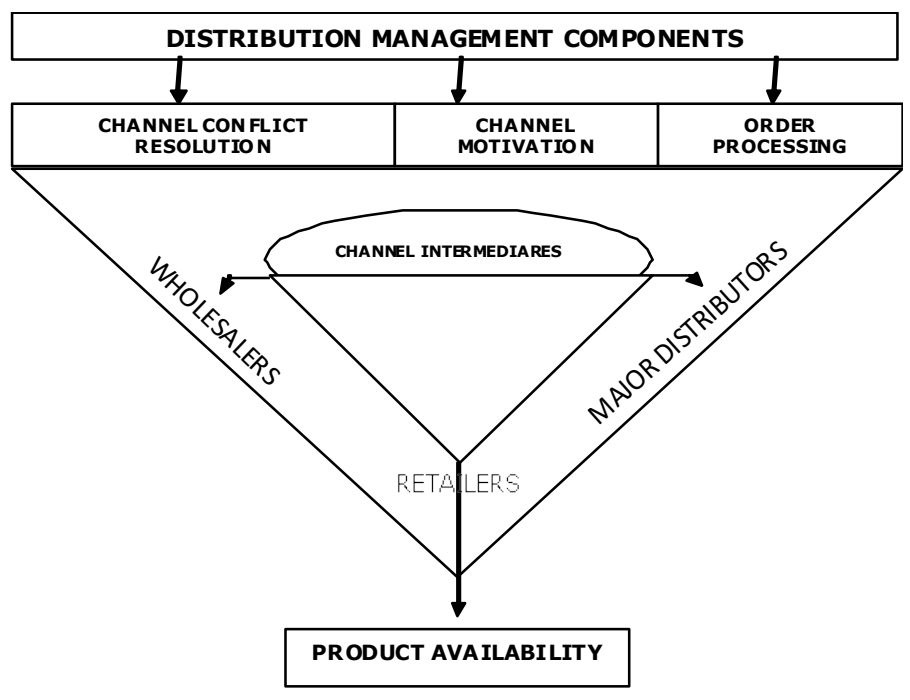

Source: Developed by the researcher

From the above model, and based on the goal setting theory which happens to be the auspices of this study the researcher views product availability as the ultimate goal of distribution management which productive firms must strive to accomplish using various distribution management components such as channel conflict resolution, channel motivation and order processing to coordinate the activities of channel intermediaries like the distributors, wholesaler sand retails in order to further facilitate the accomplishment of the distribution management objective which is product availability. 


\section{HISTORICAL BACKGROUND}

Guinness Nigeria Plc as a subsidiary of Diageo Plc of the United States was incorporated in 1962 with the building of a brewery in Ikeja, The heart of Lagos. This brewery in Lagos was the first outside of Ireland and Great Britain.

Guinness stout which was first exported to Sierra Leone in 1827 became more popular in West Africa following its desire to be transformed into a manufacturing operation whose major activities was to continue in the brewing, packaging and selling of Guinness brands which ranges from Guinness Foreign Extra Stout, Guinness extra smooth, Harp Larger, Satzenbrau, Gordon Spark, Smirnoff ice, Malta Guinness, Armstrong dark beer.

Guinness Nigeria as a productive firm has experienced steady growth which has led it to be quoted in 1965 in the Nigerian stock exchange and also promoted the building of four major Breweries across Nigeria which are located in Benin, Ogba, Ikeja and Aba respectively.

Guinness Nigeria which has a mission statement of becoming one of the world's most respected company has been able to distinguish itself from other competing breweries by remarkably increasing its production capacity to meet the growing demand for its product and as such Guinness Nigeria is committed to enriching communities in which it operates by actively involving in socio-economic development of Host communities through the performance of social responsibility ranging from the provision of clean portable water to health and education, Thus enabling Guinness Nigeria in 2007 to become the first brewery in West Africa to be ISO 1400:2004 certified with the highest certification available for clean environmental standards globally.

\section{Study Area}

This study on the impact of distribution management on the product availability of Guinness Nigeria plc is conducted in Calabar which is the state capital of Cross River State and is located in the south-south geographical zone of Nigeria. For the purpose of administration, the city is divided into Calabar Municipality and Calabar South Local Government. It has an area of 406 $\mathrm{km} 2$ and a population of 371,022 at the 2006 National Population Census (Wikipedia, 2012).

\section{Research Design}

The research design adopted for this study is the survey design, and this is because the survey research design enables the investigator to objectively use specific survey instruments like structured questionnaires in obtaining data.

\section{Population of the Study}

The population of this study is comprises of 37 respondents selected from the major distributors, wholesalers and the retailers of Guinness brands within and around the Calabar metropolis.

\section{Sampling Design}

The sampling design adopted for this study is the simple random sampling technique. this is because this sampling technique gives each sampling unit the equal chances of being selected and the selection of a particular element or sampling unit does not preclude the others from being selected (Etuk,2010). Moreso, in a bid to determine the sample size for this study which is the representative fraction of the population, the Taro Yamane formula would be adopted and this is because the population of the study is known and considered to be 37 .

Therefore, the Taro Yamane formula is given below as: 
Where

$$
\mathrm{n}=\frac{\mathrm{N}}{1+\mathrm{N}\left(\mathrm{e}^{2}\right)}
$$

$\mathrm{n}=$ sample size required.

$\mathrm{N}=$ Total population of the study

$\mathrm{e}=$ Limit of Error Tolerance

$\mathrm{I}=$ A constant factor

Based on the above formula a confidence level of $95 \%$ and an error tolerance of $5 \%$ would be used.

Hence,

$\mathrm{N}=37, \mathrm{E}=5 / 100=0.05$

Substituting into the above formula:

$$
\mathrm{n}=\frac{\underline{37}}{1+37\left(0.05^{2}\right)}
$$

$\mathrm{n}=33.867$ Approximately 34

Therefore, the sample size for this study is 34 .

\section{Sources of Data and Data Collection Method}

The main source of data for this study is the primary source, of which first hand data was generated through the administration of a structured five point likert scale questionnaires on the major distributors, wholesalers and retailers of Guinness Nigeria brand in Calabar. The questionnaires was subjected to a reliability test using cronbach's alpha coefficient which produced a value of 0.794 herby, making the questionnaires sufficient because the value of 0.6 and above is regarded to be sufficient (Sekaran, 1992 as cited in Sebastian, 2014).

\section{DATA ANALYSIS}

The data collected in the course of this study was presented in tables to cover for the descriptive statistics which showed the frequencies and cumulative percentages.

To ascertain the impact of distribution management components such as channel conflict resolution, channel motivation and order processing on the product availability of Guinness Nigeria plc in Calabar, Multiple regression as a statistical tool existing in the statistical package for the social sciences (SPSS version 21) was used.

\section{Research hypotheses And Analysis \\ Hypotheses}

$\mathbf{H}_{1}$ : Channel conflict resolution, channel motivation and order processing have an impact on the availability of Guinness Nig.plc.

$\mathbf{H}_{\mathbf{0}}$ : Channel conflict resolution, channel motivation and order processing does not have an impact on the availability of Guinness products in Calabar Nigeria Plc 
Table 4.1 : Regression Model Summary showing the impact of Channel conflict resolution, Channel motivation and Order processing on the product availability of Guinness Nig.Plc.

\begin{tabular}{|l|l|l|l|l|}
\hline Model & $\mathrm{R}$ & R Square & Adjusted R Square & Std. Error of the Estimate \\
\hline 1 & $.730^{\mathrm{a}}$ & .533 & .487 & .88207 \\
\hline
\end{tabular}

a. Predictors: (Constant), Channel conflict resolution, Channel motivation and Order processing.

b. Dependent Variable: Product availability

Table 4.1.2: ANOVAa showing the impact of Channel conflict resolution, Channel motivation and Order processing on the product availability of Guinness Nig.plc.

\begin{tabular}{|c|c|c|c|c|c|c|}
\hline \multicolumn{2}{|c|}{ Model } & Sum of Squares & $\overline{D f}$ & Mean Square & $\mathrm{F}$ & Sig. \\
\hline & Regression & 26.688 & 3 & 8.896 & 11.434 & $.000^{\mathrm{b}}$ \\
\hline 1 & $\begin{array}{l}\text { Residual } \\
\text { Total }\end{array}$ & $\begin{array}{l}23.341 \\
50.029\end{array}$ & $\begin{array}{l}30 \\
33\end{array}$ & .778 & & \\
\hline
\end{tabular}

a. Dependent Variable: Product availability

b. Predictors: (Constant), Channel conflict resolution, Channel motivation and Order processing

Table 4.1.3: Coefficientsa showing the impact of channel conflict resolution, channel motivation and order processing on the product availability of Guinness Nig.plc.

\begin{tabular}{|c|c|c|c|c|c|c|}
\hline \multirow{2}{*}{\multicolumn{2}{|c|}{ Model }} & \multicolumn{2}{|c|}{$\begin{array}{l}\text { Unstandardized } \\
\text { Coefficients }\end{array}$} & \multirow{2}{*}{$\begin{array}{l}\text { Standardized } \\
\text { Coefficients } \\
\text { Beta }\end{array}$} & \multirow[t]{2}{*}{$\mathrm{t}$} & \multirow[t]{2}{*}{ Sig. } \\
\hline & & B & $\begin{array}{l}\text { Std. } \\
\text { Error }\end{array}$ & & & \\
\hline \multirow{4}{*}{1} & (Constant) & 2.517 & .908 & & 2.771 & .010 \\
\hline & $\begin{array}{l}\text { Channel conflict } \\
\text { resolution }\end{array}$ & .003 & .096 & .004 & .029 & .977 \\
\hline & Channel motivation & .073 & .080 & .124 & .911 & .370 \\
\hline & Order processing & .470 & .092 & .678 & 5.106 & .000 \\
\hline
\end{tabular}

a. Dependent Variable: product availability

\section{RESULT INTERPRETATION}

The correlation and regression analyses were conducted to examine the relationship between distribution management components and the product availability of Guinness Nigeria. Plc to channel intermediaries in Calabar. Table 4.1.3 above summarizes the descriptive statistics and the results of the analysis. The multiple regression model with all three variable predictors produced an $\mathrm{R}$-square $=.533, \mathrm{~F}(3,53)=11.434, \mathrm{P}<.05$, the model has a correlation coefficient of .73.The $t$ test value were The value of the coefficient correlation shows that there is a very strong impact between the predictor's variables and criterion variable, which implies that channel conflict resolution, channel motivation and order processing have a significant and positive impact on product availability of Guinness. The $\mathrm{R}$-square value of .53 shows that about 53 percent of distribution management of Guinness brand is explained by the predictors' variables. Though the $\mathrm{t}$ values of the predictors variable; Channel conflict resolution; .977, channel motivation;.397 and order processing;.000, shows that order processing can be concluded to significantly impacting on the product availability of Guinness brand. 


\section{DISCUSSION OF FINDINGS}

The impact of distribution management on the product availability of Guinness products has clearly been established and the result of the above data analysis shows that the various distribution management components such as channel conflict resolution, channel motivation and order processing do all have an impact on the product availability of Guinness Nigeria plc ,but the impact of channel conflict resolution and channel motivation tend to be insignificant.

Supporting the impact of channel conflict on product availability Wilkinson(1973) opines that channel members need to operate as an integrated whole in order to attain efficiency which can only be attained with an effective cooperation through a proper channel conflict resolution technique.

Supporting the impact of channel motivation on product availability, Linton (2014) opines that channel motivation helps to build a strong brand preference for a manufactures product which in turn increases sales, influences channel members behavior and above all achieves product availability by ensuring that the right products are available at the right place and at the right time.

Conclusively, supporting the impact of order processing on product availability as indicated by the assym sign of .0000 which is less than the significant level of $.05(p<0.05)$, Wisegeek (2015) an online blogger opined that an efficient and accurate order processing is essential to the success of any business, and for any business to be successful it must ensure that its product are delivered to the right people in the right place and at the right time.

\section{CONCLUSION}

In conclusion, the study reveals that distribution management has an impact on the product availability of a firm and as such the distribution management components such as channel conflict resolution, channel motivation tends to insignificantly impact on product availability of a firm while order processing remains the most significant component of distribution management that impacts on the product availability of a firm.

\section{RECOMMENDATION}

1. Guinness should focus more on expediting her order processing methods because it most significantly ensures the availability of a firms product more than any other operational distribution management component.

\section{References}

Agbonifoh, A. B., Ogwo, O. E. and Nnolim, A. D. (1999). Marketing in Nigeria: principles and practice. Aba: Afritower Ltd.

Bowersox, D. J. \& Cooper, M. B. (1992). Strategic marketing: channel management. New York: McGraw-Hill Inc.

Buyline Report (2008). Marketing performance measurement. Target areas where marketers want to improve and how they measure up. Available at www.businessresearch.com.

Cespedes, F. \& Corley, E. C. (1990). Managing multiple channels, Business Horizons July/August, pp. 66-77.

Drucker, P. (1973). Management tasks, responsibilities and practice. New York: Harper and Row.

Ebitu, E. T. (2003). Distribution and logistics management. Uyo: Eddynoll Publishers.

Ehikwe, A. E \&Egboro, F. (2014). Challenges of channel conflict management in soft drinks. International Journal of Management and Information Technology, No. 19: vol. 1.

Esu, B. B. (2005). Introduction to marketing, Calabar: Jochrisam Publishers.

Etuk, E. J. (2010). Business research methods. Concepts, processes and application, Calabar: University of Calabar Printing Press. 
Gupta, S. (2013). Motivating the channel members. MBA - 49 - 2013.

Hesket, J. (2003). Marketing, New York: Macmillan Publishing Company.

Inyang, B. (2002). Management theory: principles and practice. Calabar: Merb Publishers.

Jain, S. C. (1991). Marketing planning and strategy. Cincinnati: South Western Publishers Company.

Kim, J. S. (1984). Effect of behaviour plus goal setting and feedback on employee satisfaction and performance. Academy of Management Journal. (3):139-149.

Kotler, P. (2005). Principles of marketing. European $4^{\text {th }}$ edition. Harlow: Pearson Publishers.

Kotler, P. \& Keller L. (2007). Marketing management. New York: Pearson Education Inc.

Kotler, P., Keller L. \& Button (2009). Marketing management. Pearson Education, Australia: French Forest.

Locke, E. (1968). Towards a theory of task motivation and incentives handbook: organizational behaviour and human performance. New York: MarcebDoker.

Locke, E. \&Lathem G. (2002). Building a practically useful theory of goal setting and task motivation: A 35 years Oddysey American Psychologist. 57(9):705-717.

Linton, L. (2014). Business and entrepreneurship index. Available at www.businessentrepreneurship.com.

Onah, J. and Thomas, M. (2004). Marketing management: strategies and cases. Enugu: Institute of Development Studies.

Pelton, L., Stutton, D. and Lumpkin, U. (1997). Marketing channels: A relationship management approach. Boston: Irwin McGraw Hill.

Pennslyvania State University World Campus (2012). Psyche 484 lesson 6. Goal setting theory, what am I trying to achieve in my work? Work attitude and motivation.

Pennslyvania State University World Campus (2014). Psyche 484 lesson 6. Goal setting theory, what am I trying to achieve in my work? Work attitude and motivation

Savinhas, A. \& Anderson E. (2005). How potential conflict drives channel structure. Journal of Marketing Research. No. 42:507-515.

Stern, L., Ansary A. and Coughlan, T. (1991). Marketing channels. New Delhi: Prentice Hall of India.

Wilkinson, L. (1973). Distribution channel management. Power considerations. International Journal of Physical Distribution. 4(1):4-15.

William, J. T., Michael, E., and Bruce, J. W. (1994). Fundamentals of marketing. Singapore: McGraw Hill Inc.

Yagana, B. I. (2014). Effective channel management. Journal of Finance and Accounting.5(18). 